\title{
Role of A Student in The Field of Biotechnology from Developing World
}

\author{
Anjali $\mathbf{M}^{*}$ \\ Department of Biotechnology, GS Medical College, India
}

Submission: February 03, 2018; Published: August 27, 2018

*Corresponding author: Anjali M,Department ofBiotechnology,GS Medical College, India; Email: anjali.anjupossible@gmail.com

\begin{abstract}
The life sciences offer many wide varieties of opportunities for revolutionizing human welfare activities. "Biotechnology is a applied branch of science which deals with the application of principal of processand productsof living beingsfor thebettermentof mankind"sometimesshortened to "Biotech". Enriched by the inputs from genomic research biotech in a major force for development in all countries. Entwined or involved in culture and socio- ethical values, biotech contributes to solving problems like medicinefoodand water, insecuritythat impedesnational development and threatenpeace in the developing world Long years ago people used to apply the technology in variousfields like selectivebreeding,microbial culture, antibiotics etc. The four major applications of these all industrial area, health care crop production and agriculture. Several branches of there all Ex: Bio-informatics, Blue, Green, Red and white biotechnology.The practice of bio-tech is different in many developing countries. The establishment of biotechnology parks andmedicinal plant farms may give high policy status in national development.

So, hereby I can say that bio-technology is very necessary for mankind todevelop ourcounty likehow the production of drugs, Medicinesetc., in larger scale quantity. By this we can export to other countries, and also mainly in the field of tissue culture. In one word we can say biotechnology is a boon for the students to develop our country.
\end{abstract}

Keywords: Biotechnology; Industrial area; Medicine; Drugs

\section{Introduction}

The applied branch of science deals with the application of principles, process and products for the betterment of mankind is known as biotechnology. A life science offers wide varieties of opportunities for revolutionizing human welfare activities enriched by the inputs from genomic research bio-tech and is a major force for development in all countries entwined or involved in culture and socio-ethical values. Biotech contributes to solving problems like medicine, food and water scarcity, which impedes development of a country and threaten Piece in the developing world. Biotechnology is in use from long years ago (7000 years) and is also conserved to the present world.

Agriculture has been theorized to have become the dominant way of producing food, since the Neolithic revolution. The process and methods of agriculture have been refined by other mechanical and biological science since its inception. Through the use of agriculture, farmers have altered the genetics of the essential crops by introducing novel crops to a new environment and breeding them with other plants-one of first forms of biotechnology. Thousands of years ago, humans have used selective breeding to improve production of crops and livestock to use them for food. In selective breeding organisms or with desirable characteristics are mated to produce off-springs with same character.

In 1917, Chaim weizamann first used a pure micro-biological culture in an industrial process, that of manufacturing corn starch using Clostridium acetobutylicum to produce acetone. Biotechnology has also lead to the development of antibiotics. In 1928, Alexander Fleming discovered the mold penicillin. This is used to treat bacterical infections in human.

Biotechnology has the applications in industrial areas, medical health care, crop production and agriculture. Nowadays, interest in the traditional fermentation technology for food processing has greatly increased because of emphasis placed upon plant materials as human foods. Single-cell protein (SCP) is term generally accepted to mean the microbial cells (algae, bacteria, actinomycetes and fungi) grown and harvested for animal or human food. During World War II, when there were shortages in proteins and vitamins in the diet, the Germans produced yeasts and a mold (Geotrichumcandidum) in some quantity for food. Research on SCP has been stimulated by a concern over the eventual food crisis or food shortages that will occur if the world's 
population is not controlled. Many scientists believe that the use of microbial fermentations and the development of an industry to produce and supply SCP are possible solutions to meet a shortage of protein if and when the amount of protein produced or obtained by agriculture and fishing becomes insufficient.

\section{Different Types of Biotechnology}

Here are numerous sub-fields of biotechnology. They are:

Red biotechnology is biotechnology applied to medical processes. Some examples are the designing of organisms to produce antibiotics, and the engineering of genetic cures to cure diseases through genomic manipulation.

White biotechnology, also known as grey biotechnology, is biotechnology applied to industrial processes. An example is the designing of an organism to produce a useful chemical. White biotechnology tends to consume less in resources than traditional processes when used to produce industrial goods.

Green biotechnology is biotechnology applied to agricultural processes. An example is the designing of an organism to grow under specific environmental conditions or in the presence (or absence) of certain agricultural chemicals. One hope is that green biotechnology might produce more environmentally friendly solutions than traditional industrial agriculture. An example of this is the engineering of a plant to express a pesticide, thereby eliminating the need for external application of pesticides. Whether or not green biotechnology products such as this are ultimately more environmentally friendly is a topic of considerable debate. The term blue biotechnology has also been used to describe the marine and aquatic applications of biotechnology, but its use is relatively rare.

\section{Broadly biotechnology can be divided into two major branches:}

a. Non-gene biotechnology-Deals with whole cell, tissues or even individual organisms

b. Gene biotechnology- Involves gene manipulation, cloning, etc.

Non-gene biotechnology is a more popular practice, and plant tissue culture.

\section{Biotechnology Can Also Be Used to Overcome Hunger}

a. One amongst every six persons, in the developing world, has no access to food

b. Of830 million people suffering from malnutrition and hunger790 million live in developing countries, often, home of the poor and hungry 80 million children under 4 years of age are malnourished

c. The undernourished subsist on 1,800 calories per day or less instead of a general requirement of 2000 per adult per day d. At the World Food Summit (1996), 186 countries committed pledged a reduction by half in the number of undernourished people by 2015

\section{Poverty}

a. As a rule, hunger is a direct consequence of dire poverty

b. Seventy per cent of the world's poor live in rural areas

c. Poverty, essentially a rural phenomenon, is creeping into urban areas

d. 2.8 billion people live on less than US $\$ 2$ per day

e. Of the 1.3 billion people in the sub-region of South Asia

f. 800 million live on less than US\$ 1 per day

g. 230 million lack access to safe water

h. $\quad 100$ million children live or work on the streets

i. In 1998, the 48 poorest countries attracted less than US $\$ 3$ billion inforeign investments

j. Poverty in urban areas in coming decades will overtake rural numbers

k. Some 650 million people in Asia (300 million), in Africa and Latin America (150 million each) live in urban areas below the internationally- accepted poverty line of US $\$ 1 /$ day

\section{Population}

a. Of the approximately 90 million newborn, $95 \%$ are born in developing countries

b. 40 million births each year are not registered worldwide

c. $\quad 70 \%$ of people in the developing countries below the poverty line are rural women

d. Of the approximately 1100 million farmers worldwide 50 million farmers are in the developed world1050 million farmers with little financial resources are in the developing countries

e. By 2050, two-thirds of the world's population is likely to be urban

f. $\quad 90$ per cent of the world's population will begin life in a developing country

g. Developing countries account for about 78 per cent of the world's population

\section{GMO considerations}

a. Benefits poor-resource farmers in use of number/ amount of herbicides/pesticides

b. High yields and more productive crops are part of the solution to the global food crisis 
c. No evidence that commercial transgenic crops contain new allergens nor have negative impact on human health

d. Genetic engineering techniques generally are applied to crops important to the industrialized world, and less to crops on which the world's hungry depend

e. Global GM crop area estimated to be a little over 50 million hectares

f. Fears concerning GM foods and crop result from:

g. Occurrence spread and ignorance of Mad Cow Disease in Europe

h. Reported occurrence of chemical dioxin in foods, soft drinks; sludge in animal food

i. Inclusion of GM food in animal in food for humans (tortillas)

j. Concentration of seed companies in a few hands

k. Lack of, and/or inadequate tests of GM crops in tropical environments

l. Improper identification and labelling of GM foods in food markets

m. Absence of public awareness and consumer education programmed

\section{Biotechnology Parks and Medicinal Farms}

In the continuing quest for economic advancement and technological development, several developing countries have embraced the concept of biotechnology parks that combine scientific enquiry with R\&D biotech savoir-faire to yield potential market products. With this raison de faire, biotechnology parks use an amalgam of entrepreneurial energies and networking skills to promote co-development of biotech processes, to transfer biotech know-how, and to provide technical services. In brief, biotechnology parks incorporate incentives that provide for an academic environment unencumbered by bureaucratic guidelines; that transform concepts and ideas into environmentfriendly bioindustries, and that attract start-up angel, seed and venture capital, and tax exemptions. Biotechnology parks in several developing countries reveal a political commitment in transforming the potential of modern biotechnology knowledge into reality for the benefit of all strata of society

\section{Medicinal Plants}

a. $80 \%$ of the world's people rely on traditional medicine for their daily health needs

b. In the 1990s consumption of herbal medicine in Western Europe doubled

c. About one in four of all prescription drugs dispensed by Western pharmacists are likely to contain ingredients derived from plants d. Chamomile harvest provides some 15,000-20,000 people with work each year in Hungary

e. Some 150 medicinal plants in Europe are considered to be endangered

f. The global market for medicinal markets is expected to grow from US $\$ 10$ billion in 2001 to US $\$ 40$ billion in 2010 with Europe accounting for a large part of this market

\section{Women in Partnership with Biotechnology}

a. African proverb: Without women we all go hungry

b. In developing countries women produce $75 \%$ of the food

c. Women work two-thirds of the world's working hours, earn one-tenth of the world's income and possess less than one-tenth of the world's property

d. In the Andean region an estimated 40 per cent of women agricultural producers play an important role in food security

\section{Successful Women's in the field of Biotechnology}

a. Kiran Mazumdar-Shaw[founder of biocon]

b. Dr.Preetireddy[M.D-APOLLO HOSPITALS]

c. Dr.Swati A Piramal[Vice chairperson of Piramal groups]

d. Vinitha Gupta[CEO-Lupin Pharamaceuticals]

e. Katrine Bosley[CEO-Avila Therapeutics]

f. Susan Desmond-Hellmann[Chancellor- UCSF]

g. Deborah Dunsire[Millennium, theTakeda Oncology Company-President and CEO]

h. Carol Gallagher[Calistoga Pharmaceuticals-CEO]

i. Melinda Gates[Bill \& Melinda Gates FoundationFounder]

\section{j. Maxine Gowen [Trevena- President \& CEO}

k. RachelKing[GlycoMimeticsCEO]

\section{Strategic biotech initiatives in the developing world}

Developing countries are already devising and using strategic biotechnologies to solve problems of local, regional and global significance.The European Union (EU), through the Lome Convention, promotes technical co-operation with 70 countries in Africa, the Caribbean and the Pacific (ACP). Research institutes and universities are engaged in competitive breakthrough peerreviewed research are constantly attracting scientific excellence. The horizontal flow of research amongst and between developing countries strengthens South-South regional and international collaboration which involves diversification of agricultural production, industrial enterprises and a well-developed human resource base. Self-sufficiency and self-reliance, the twin hallmarks of a "stand alone" market-oriented economy are crucial 
and can be achieved only through co-operative networking and sharing of experiences, and knowledge-rich resources.

\section{Capacity-building in biotechnology for development}

Biotechnology is a cross-cutting technology encountered in wide application across several sectors of development An amalgam of a variety of disciplines -biochemistry, the engineering sciences, genetics, informatics, molecular biology and microbiology, the neurosciences and nanotechnology amongst others, biotechnology makes important contributions to the new knowledge-based economy and markets.

\section{Conclusion}

So, here by I conclude that a student plays a significant role in developing the world by their contribution in production of drugs in large quantity, to export abroad and also in the health care. For example- in preparation of the medicines. The foremost important thing in the field of agriculture, is the increased production of plants using the biotechnology tools and tissue culture. We can also produce different types of food materials essential for the mankind. In one word, we can say that biotechnology is a boon for the students, research scholars, scientists, farmers etc.., to utilize and to develop our country as No.1 in the world.

\section{Your next submission with Juniper Publishers will reach you the below assets}

- Quality Editorial service

- Swift Peer Review

- Reprints availability

- E-prints Service

- Manuscript Podcast for convenient understanding

- Global attainment for your research

- Manuscript accessibility in different formats ( Pdf, E-pub, Full Text, Audio)

- Unceasing customer service

Track the below URL for one-step submission https://juniperpublishers.com/online-submission.php 